Article

\title{
Treatment of Landfill Leachates with Combined Acidification/Coagulation and the $\mathrm{Fe}^{0} / \mathrm{H}_{2} \mathrm{O}_{2}$ Process
}

\author{
Jan Bogacki * (D), Piotr Marcinowski ${ }^{(\mathbb{D})}$ and Balkess El-Khozondar \\ Faculty of Building Services, Hydro and Environmental Engineering, Warsaw University of Technology, \\ Nowowiejska 20, 00-653 Warsaw, Poland; piotr.marcinowski@pw.edu.pl (P.M.); \\ balkess-elkhozondar@hotmail.com (B.E.-K.) \\ * Correspondence: jan.bogacki@pw.edu.pl; Tel.: +48-22-234-5423
}

Received: 21 December 2018; Accepted: 21 January 2019; Published: 23 January 2019

\begin{abstract}
One of the major environmental concerns associated with waste disposal is the large amount of generated landfill leachates (LL), which are considered a type of wastewater with a complex composition. There is an urgent need to find an effective LL treatment method. LL were subjected to pretreatment followed by the $\mathrm{Fe}^{0} / \mathrm{H}_{2} \mathrm{O}_{2}$ process. Pretreatment efficiency was coagulation at $\mathrm{pH} 6.0>>$ coagulation at $\mathrm{pH} 9.0>$ acidification at $\mathrm{pH}$ 3.0. Coagulation at $\mathrm{pH} 6.0$ in an optimal $\mathrm{Fe}^{3+}$ dose of $1000 \mathrm{mg} / \mathrm{L}$ decreased total organic carbon (TOC) from the initial concentration of $1061 \mathrm{mg} / \mathrm{L}$ to $491 \mathrm{mg} / \mathrm{L}$ while acidification to $\mathrm{pH} 3.0$ decreased TOC to $824 \mathrm{mg} / \mathrm{L}$. After acidification, the $\mathrm{Fe}^{0} / \mathrm{H}_{2} \mathrm{O}_{2}$ process with $8000 / 9200 \mathrm{mg} / \mathrm{L} \mathrm{Fe}^{0} / \mathrm{H}_{2} \mathrm{O}_{2}$ reagent doses decreased TOC to $499 \mathrm{mg} / \mathrm{L}$ after a processing time of $60 \mathrm{~min}$. Performance of the $\mathrm{Fe}^{0} / \mathrm{H}_{2} \mathrm{O}_{2}$ process after coagulation at $\mathrm{pH} 6.0$ for optimal Fe ${ }^{0} / \mathrm{H}_{2} \mathrm{O}_{2} 8000 / 5540 \mathrm{mg} / \mathrm{L}$ reagent doses decreased TOC to $268 \mathrm{mg} / \mathrm{L}$ (75\% TOC removal). Treatment of landfill leachates with combined process coagulation and $\mathrm{Fe}^{0} / \mathrm{H}_{2} \mathrm{O}_{2}$ also increased their susceptibility to biodegradation, expressed as the biochemical oxygen demand/chemical oxygen demand $\left(\mathrm{BOD}_{5} / \mathrm{COD}\right)$ ratio from 0.13 to 0.43 , allowing LL to be considered as susceptible to biodegradation. $\mathrm{Fe}^{0} / \mathrm{H}_{2} \mathrm{O}_{2}$ process kinetics was described. A statistical analysis confirmed the obtained results. The proposed method can be successfully applied for LL treatment.
\end{abstract}

Keywords: landfill leachates; wastewater treatment; advanced oxidation processes; zero-valent iron; biodegradation

\section{Introduction}

Solid waste generation is strongly affected by human activities. As population growth increases rapidly, waste generation also increases in the same way. In the European Union, nearly $1.323 \mathrm{~kg}$ of municipal waste is generated per person per day [1]. Due to the insufficient efficiency of waste separation, reuse, and recycling [2], only $29 \%$ of the waste is recycled and the remainder is disposed directly in landfills [1]. One of the major environmental concerns associated with waste disposal is the large amount of generated landfill leachates (LL) due to the rainwater filtration through waste. LL can be considered wastewater with a complex composition and many toxic and persistent compounds [3]. Their composition depends on many factors, such as the landfill age, climatic conditions, rainfall intensity, and the presence of toxic/biorefractory wastes in the landfill [4-7]. Because of the high variability of the flow and type of pollutants in LL, the traditional activated sludge reactors used in typical wastewater treatment plants are not efficient enough [4] for it. The worldwide wastewater discharge regulations and standards have become stricter; hence, there is an urgent need to find an effective LL treatment method. Many researchers are investigating new and effective methods for LL treatment, such as sorption on magnetic particles [2] and other sorbents [8], reactive granular filters [9], the use of metallic iron $[4,10,11]$ and other heterogeneous catalysts $[12,13]$, Fenton (classical 
and solar) [14-17], electro-Fenton [18,19], and other electrochemical processes [11,20-24], usage of different oxidants and their combination [25,26], microwaves [10], ultrasounds [27], membrane processes [28], hydrodynamic cavitation [29], microalgae [30], biofiltration [21,31], supercritical water oxidation [32], oscillating biological membrane photoreactors [33], anaerobic digestion [27,34], dynamic membrane bioreactors [35], bio-electro-Fenton [36], upflow sludge bed reactors [37], moving bed biofilm reactors [38], and the sequencing batch reactor [39]. Moreover, a few review articles have summarized the LL treatment methods [40-46].

Chen et al. [10] applied, among others, the $\mathrm{Fe}^{0} / \mathrm{H}_{2} \mathrm{O}_{2}$ process for LL treatment. After a process time of $14 \mathrm{~min}$, only $17.9 \%$ chemical oxygen demand (COD) was removed for $0.5 \mathrm{~g} \mathrm{Fe}$ and $20 \mathrm{~mL} / \mathrm{L}$ $\mathrm{H}_{2} \mathrm{O}_{2}$ reagent doses. One could expect that if the process was extended, the results would be much higher. Small COD removal could be also related to low $\mathrm{Fe}^{0}$ dose and a big $\mathrm{H}_{2} \mathrm{O}_{2} / \mathrm{COD}$ ratio. Ertugay et al. [47] applied the $\mathrm{Fe}^{0} / \mathrm{H}_{2} \mathrm{O}_{2}$ process for LL treatment for small 50/150 mg/L reagent doses in a wide acidic $\mathrm{pH}$ range. The COD efficiency at $\mathrm{pH} 3.0$ was only $\sim 20 \%$, while at $\mathrm{pH} 2.0$, it reached $\sim 75 \%$. Martins et al. [4], on the contrary, tried high $\mathrm{Fe}^{0}$ doses of up to $125 \mathrm{~g} / \mathrm{L}$ in the form of iron shavings as well as a low $\mathrm{H}_{2} \mathrm{O}_{2}$ /COD ratio, and obtained a COD removal of up to $48 \%$. Soubh et al. [13] used a combination of metallic iron, graphene oxide, and persulfate for LL treatment. The impacts of significant parameters on the removal of $\mathrm{COD}$ and $\mathrm{NH}_{3}$ were evaluated. The removal efficiencies for the fresh leachate were $80.87 \%$ and $72.38 \%$, respectively, and the biochemical oxygen demand/chemical oxygen demand $\left(\mathrm{BOD}_{5} / \mathrm{COD}\right)$ ratio increased from 0.25 to 0.52 , respectively.

Advanced oxidation processes (AOP) consist of the efficient production of free radicals (primarily $\mathrm{HO}^{\bullet}$ ) that effectively oxidize pollutants contained in the wastewater. In the $\mathrm{Fe}^{0} / \mathrm{H}_{2} \mathrm{O}_{2}$ process, under acidic conditions and as a result of the dissolution processes, the metallic iron becomes a $\mathrm{Fe}^{2+}$ ion source. $\mathrm{Fe}^{2+}$ ions undergo oxidation to $\mathrm{Fe}^{3+}$ in the presence of $\mathrm{H}_{2} \mathrm{O}_{2}$, while $\mathrm{H}_{2} \mathrm{O}_{2}$ undergoes conversion to $\mathrm{HO}^{\bullet}$ and $\mathrm{OH}^{-}$. Reactions 1-5 allow for divalent iron ion production, while reactions 6-7 describe the creation process chemistry of radicals [48].

To our knowledge, most Polish landfills do not conduct any leachate treatment. Only several landfills pretreat leachates, usually with $\mathrm{pH}$ adjustment and membrane processes. Mostly, the leachates are transported by slurry tankers to municipal wastewater treatment plants. Often, municipal wastewater treatment plants report that the provision of leachate causes problems for their proper functioning. The aim of this study is to assess the possibility of using the $\mathrm{Fe}^{0} / \mathrm{H}_{2} \mathrm{O}_{2}$ process to decrease the organic pollutant load and increase the $\mathrm{LL} \mathrm{BOD}_{5} / \mathrm{COD}$ ratio. LL were subjected to pretreatment followed by the $\mathrm{Fe}^{0} / \mathrm{H}_{2} \mathrm{O}_{2}$ process. For the pretreatment process, alternatively, acidification or coagulation at $\mathrm{pH} 6.0$ or 9.0 was used. Then, the $\mathrm{Fe}^{0} / \mathrm{H}_{2} \mathrm{O}_{2}$ process was applied. For both pretreatment and treatment processes, different reagent doses were tested.

\section{Materials and Methods}

\subsection{Sample Collection and Experiment Preparation}

LL were collected from a Polish landfill. The raw leachate characteristics are presented in Figure 1 and in Table 1. All experiments were conducted within $72 \mathrm{~h}$ of the sample collection and were carried out in duplicate. The LL were subjected to pretreatment, followed by the $\mathrm{Fe}^{0} / \mathrm{H}_{2} \mathrm{O}_{2}$ process. As a pretreatment, three processes were used alternatively: coagulation with iron-based coagulant at $\mathrm{pH} 6.0$ or 9.0 and precipitation after acidification to $\mathrm{pH}$ 3.0. After LL collection, samples were refrigerated at $4{ }^{\circ} \mathrm{C}$ until analysis. All of the used reagents were of analytical grade. 


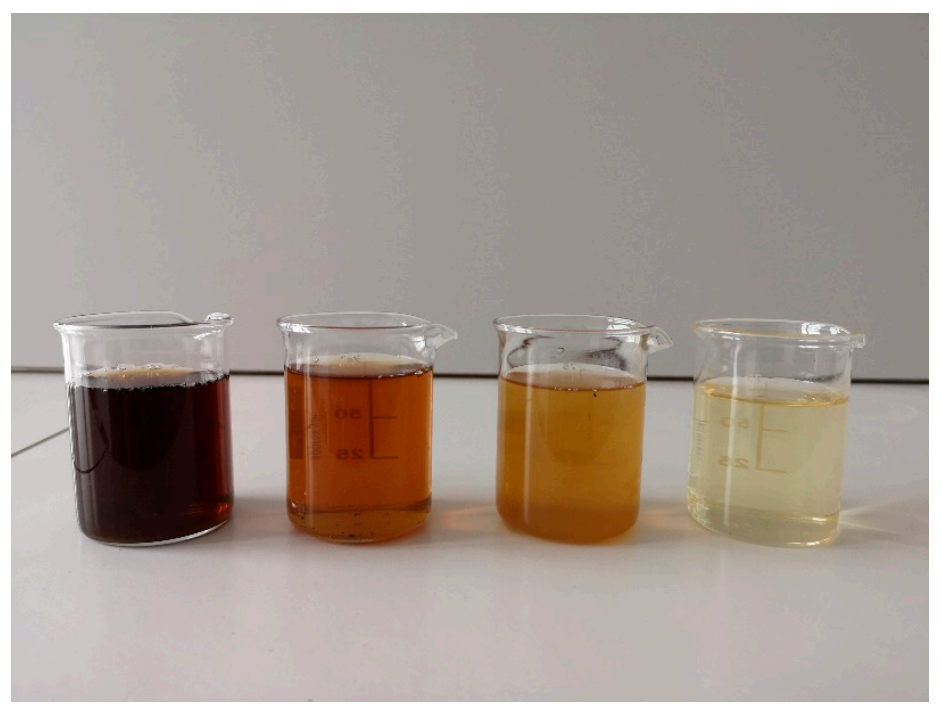

Figure 1. Color evolution of landfill leachates during treatment. From the left: (1) raw leachates; (2) acidified to $\mathrm{pH} 3.0$ after sludge removal; (3) after coagulation with $1000 \mathrm{Fe}^{3+} \mathrm{mg} / \mathrm{L}$ at $\mathrm{pH} 6.0$ and sludge removal; and (4) after the $\mathrm{Fe}^{0} / \mathrm{H}_{2} \mathrm{O}_{2}$ process and sludge removal.

Table 1. Raw landfill leachates parameters.

\begin{tabular}{lll}
\hline Parameter & Unit & Value \\
\hline $\mathrm{pH}$ & - & 7.65 \\
Conductivity & $\mathrm{mS} / \mathrm{cm}$ & 11.08 \\
TOC & $\mathrm{mg} / \mathrm{L}$ & 1061 \\
$\mathrm{TOC}_{\text {DIS }}$ & $\mathrm{mg} / \mathrm{L}$ & 1022 \\
$\mathrm{COD}$ & $\mathrm{mg} / \mathrm{L}$ & 2967 \\
$\mathrm{COD}_{\text {DIS }}$ & $\mathrm{mg} / \mathrm{L}$ & 2928 \\
$\mathrm{BOD}_{5}$ & $\mathrm{mg} / \mathrm{L}$ & 400 \\
$\mathrm{BOD}_{5} / \mathrm{TOC}$ & - & 0.377 \\
$\mathrm{BOD}_{5} / \mathrm{COD}$ & - & 0.135 \\
$\mathrm{TKN}_{\mathrm{Amm}}$ & $\mathrm{mg} / \mathrm{L}$ & 1410 \\
TSS & $\mathrm{mg} / \mathrm{L}$ & 1337 \\
Color & $\mathrm{mg} / \mathrm{L}$ & 81 \\
\hline
\end{tabular}

\subsection{Treatment Processes}

\subsubsection{Pretreatment}

The coagulation process was carried out in a $2 \mathrm{~L}$ reactor filled with $1 \mathrm{~L}$ of sample. The coagulation processes were set under two $\mathrm{pH}$ levels - 6.0 and 9.0-based on initial experiments (data not shown). The samples were stirred using a magnetic stirrer (Heidolph MR3000, Schwabach, Germany) for 5 min on fast (500 rpm), followed by $10 \mathrm{~min}$ on slow $(50 \mathrm{rpm})$ stirring. $\mathrm{FeCl}_{3}$ (POCh, Gliwice, Poland) solution in concentration $50 \mathrm{mg} \mathrm{Fe} \mathrm{m}^{3+} / \mathrm{mL}$ was used as the coagulant. Furthermore, $3 \mathrm{M} \mathrm{NaOH}$ (Stanlab, Lublin, Poland) and 10\% $\mathrm{HCl}$ (POCh, Gliwice, Poland) were used for $\mathrm{pH}$ adjustment during fast stirring. The samples were left overnight for sludge sedimentation.

A wide range of coagulant doses was used. The first dose was considered the minimal one for which the coagulation effect of the sediment precipitation could be observed. A constant step in the dose increment of the $250 \mathrm{mg} / \mathrm{L}$ coagulant was used.

Acidification to $\mathrm{pH} 3.0$ was carried out in a $2 \mathrm{~L}$ reactor filled with $1 \mathrm{~L}$ of sample. The sample was left overnight for sludge sedimentation. $\mathrm{pH} 3.0$ was selected due to the minimal salinity increase associated with the use of reagents for $\mathrm{pH}$ correction. Furthermore, for the $\mathrm{Fe}^{0} / \mathrm{H}_{2} \mathrm{O}_{2}$ process, it is 
considered optimal. Because of this, there was no need for $\mathrm{pH}$ adjustment between the acidification and $\mathrm{Fe}^{0} / \mathrm{H}_{2} \mathrm{O}_{2}$ processes.

\subsection{2. $\mathrm{Fe}^{0} / \mathrm{H}_{2} \mathrm{O}_{2}$ Process}

After pretreatment, the sample was subjected to the $\mathrm{Fe}^{0} / \mathrm{H}_{2} \mathrm{O}_{2}$ process. The $\mathrm{Fe}^{0} / \mathrm{H}_{2} \mathrm{O}_{2}$ process was carried out in a $2 \mathrm{~L}$ reactor filled with a $1 \mathrm{~L}$ sample. Solid $\mathrm{Fe}^{0}$ (Hepure, Hillsborough, NJ, USA) and $30 \% \mathrm{H}_{2} \mathrm{O}_{2}$ solution (Stanlab, Lublin, Poland) were used. Wastewater samples were stirred (500 rpm) on a magnetic stirrer (Heidolph MR3000, Schwabach, Germany). The $\mathrm{pH}$ during the $\mathrm{Fe}^{0} / \mathrm{H}_{2} \mathrm{O}_{2}$ process was set to 3.0. After specified times, $(15,30$, and $60 \mathrm{~min})$, the $\mathrm{Fe}^{0} / \mathrm{H}_{2} \mathrm{O}_{2}$ process was stopped by increasing the $\mathrm{pH}$ to 9.0 using $3 \mathrm{M} \mathrm{NaOH}$. Samples were left overnight to allow hydrogen peroxide decomposition and iron-based sludge sedimentation. Hydrogen peroxide process doses were selected according to $\mathrm{LLCOD}-1: 1,1: 2,1: 4$, and $1: 8 \mathrm{COD} / \mathrm{H}_{2} \mathrm{O}_{2}$ mass ratios. The used $\mathrm{Fe}^{0}$ in the experiments was supplied by Hepure as Ferox Target (325 mesh).

For the optimal reagent doses, process enhancement with ultrasound (US) and ultraviolet (UV) radiation was applied. $\mathrm{Fe}^{0} / \mathrm{H}_{2} \mathrm{O}_{2} / \mathrm{US}$ and $\mathrm{Fe}^{0} / \mathrm{H}_{2} \mathrm{O}_{2} / \mathrm{UV}$ processes were carried out in a $2 \mathrm{~L}$ reactor filled with a $1 \mathrm{~L}$ sample. The source of ultrasound was SONIC-5 (Polsonic, Warszawa, Poland). The ultrasound's power was $2 \times 320 \mathrm{~W}$ at $40 \mathrm{kHz}$. Medium pressure Fe/Co 400W HPA 400/30 SDC (Philips, Amsterdam, The Netherlands) lamp with 94W UVA power was used as a source of UV radiation.

\subsection{Analytical Methods}

Total organic carbon (TOC) was determined according to the EN 1484:1999 standard with a TOC-L analyzer (Shimadzu, Kyoto, Japan) with an OCT-L8-port sampler (Shimadzu, Kyoto, Japan). The combustion temperature was set to $680{ }^{\circ} \mathrm{C}$. COD, Total Kjeldahl Nitrogen (TKN), ammonia, and $\mathrm{BOD}_{5}$ concentrations were determined according to the standard methods.

\subsection{Statistical Analysis}

IBM SPSS 23.0 Statistic software (Armonk, NJ, US) was used to analyze the collaboration between the factors of the experiments. Correlation, linear regression, and optimal scaling tests were used to analyze the factors' significance.

\section{5. $\mathrm{Fe}^{0} / \mathrm{H}_{2} \mathrm{O}_{2}$ Process Kinetics Calculation}

The following equations were used to describe the kinetics of the $\mathrm{Fe}^{0} / \mathrm{H}_{2} \mathrm{O}_{2}$ process after acidification and coagulation:

(1) pseudo-first-order reaction with respect to the TOC value:

$$
\mathrm{d}[\mathrm{TOC}] / \mathrm{dt}=-\mathrm{k}_{1} \cdot[\mathrm{TOC}]
$$

(2) pseudo-second-order reaction with respect to the TOC value:

$$
\mathrm{d}[\mathrm{TOC}] / \mathrm{dt}=-\mathrm{k}_{2} \cdot[\mathrm{TOC}]^{2},
$$

(3) empirical equation that takes into account other factors that influence TOC changes:

$$
\mathrm{d}[\mathrm{TOC}] / \mathrm{dt}=-\mathrm{a} \cdot[\mathrm{TOC}] \cdot \mathrm{t}^{\mathrm{m}},
$$

where ' $\mathrm{t}$ ' corresponds to time, and ' $\mathrm{a}$ ' and ' $\mathrm{m}$ ' are constants that depend on the initial reagent concentrations. 


\section{Results}

\subsection{Raw Landfill Leachate Characteristics}

The raw LL parameters are presented in Table 1. Raw LL were characterized by high salinity and content of organic compounds. They had a deep black color and a characteristic smell. The amount of total suspended solids (TSS) was small. TOC and COD values determined in raw and filtered through $0.7 \mu \mathrm{m}$ glass filter were similar to nonfiltered ones.

\subsection{Pretreatment}

Three methods were preselected for LL pretreatment: acidification to $\mathrm{pH} 3.0$ and coagulation with $\mathrm{FeCl}_{3}$ at different $\mathrm{pH}$ values of 6.0 and 9.0. The obtained results from acidification and coagulation at $\mathrm{pH} 6.0$ and 9.0 are presented in Table 2. The evolution and the color decrease of LL during the treatment are shown in Figure 1.

The COD and TOC removal for $\mathrm{FeCl}_{3}$ coagulation at $\mathrm{pH} 6.0$ and 9.0 is shown at Figures 2 and 3 , respectively.

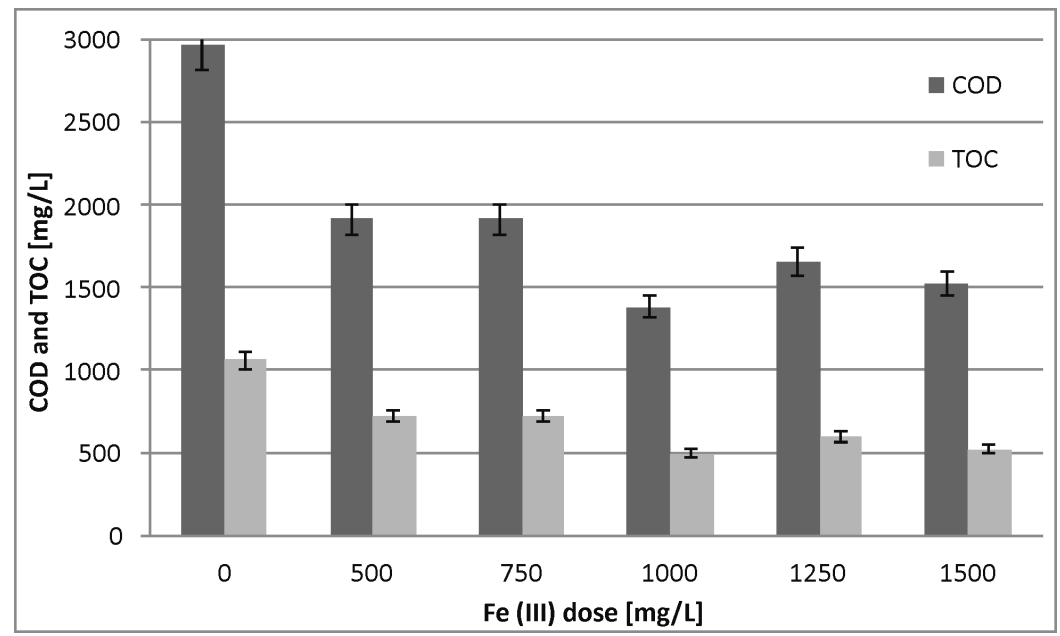

Figure 2. Total organic carbon (TOC) and chemical oxygen demand (COD) removal during coagulation with $\mathrm{FeCl}_{3}$ in $\mathrm{pH} 6.0$ for different coagulant doses.

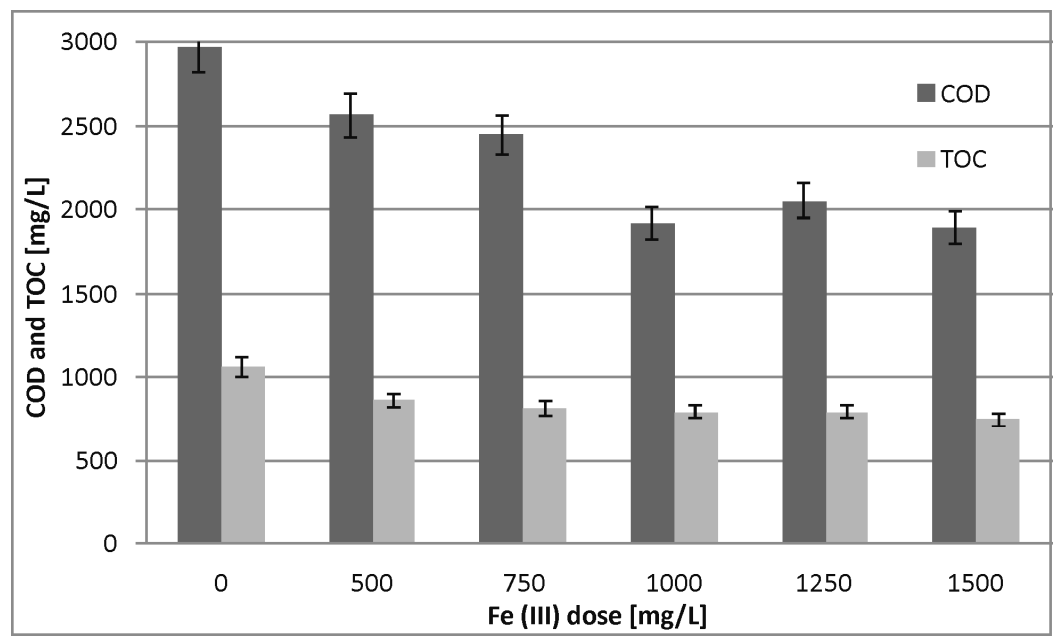

Figure 3. TOC and COD removal during coagulation with $\mathrm{FeCl}_{3}$ in $\mathrm{pH} 9.0$ for different coagulant doses.

The $\mathrm{Fe}^{3+}$ doses applied for coagulation were high, but similar to the ones applied for other types of highly loaded wastewater. In the case of acidification, only a small amount of sludge was produced 
(c.a. $50 \mathrm{~mL} / \mathrm{L}$ ). We assume that sludge produced in acidification is mostly organic and related to the low dissociation of humic acids in low $\mathrm{pH}$ regions. In coagulation, the sludge volume was, as expected, related to the coagulant dose. In the case of coagulation at $\mathrm{pH} 6.0$, for the minimal $500 \mathrm{mg} / \mathrm{L}$ coagulant dose, after $30 \mathrm{~min}$ of sedimentation, the sludge volume was $200 \mathrm{~mL} / \mathrm{L}$, and it increased up to $350 \mathrm{~mL} / \mathrm{L}$ for the $1500 \mathrm{mg} / \mathrm{L}$ dose. In case of $\mathrm{pH}$ 9.0, the sludge volume was c.a. $50 \mathrm{~mL} / \mathrm{L}$ higher for the same coagulant dose. The flocs that formed at $\mathrm{pH} 6.0$ were much bigger than those that formed at $\mathrm{pH} 9.0$.

Pretreatment requires $\mathrm{pH}$ adjustment. Acidification to $\mathrm{pH} 3.0$ requires acid usage, while coagulation, as a result of a decrease in $\mathrm{pH}$ though coagulant hydrolysis, requires the base to increase $\mathrm{pH}$ to 6.0 or 9.0. It has to be taken into account that, of course, salinity is increasing, but when we compare this with the initial salinity, expressed in terms of conductivity $(11.08 \mathrm{mS} / \mathrm{cm})$, it is not very important. A much higher degree of salinity is introduced as a result of coagulant usage. Taking into account the $\mathrm{FeCl}_{3}$ structure and molar mass, it could be concluded that $1000 \mathrm{mg} \mathrm{Fe}{ }^{3+} / \mathrm{L}$ introduces c.a. $2000 \mathrm{mg} \mathrm{Cl}^{-} / \mathrm{L}$. Such a chloride content is serious and unsolved in this article.

For both coagulation pHs, a dose of $1000 \mathrm{mg} / \mathrm{L} \mathrm{Fe}^{3+}$ could be considered optimal. However, the treatment effect at $\mathrm{pH} 6.0$ was much better in comparison with that at $\mathrm{pH} 9.0$. The TOC and COD removal during the coagulation at $\mathrm{pH} 6.0$ were shown to be dose sensitive, increasing with the dose of coagulant used. A noticeable increase in the effect of treatment was observed until the optimal dose was reached. However, after it was exceeded, a slight deterioration of the effect was observed. Similar observations were shown for the color and turbidity of the sample (data not shown). For the coagulation application at pH 9.0, similar relationships were not observed. Significantly smaller differences in the obtained TOC values as well as in the color and turbidity were observed. In the case of coagulation at $\mathrm{pH}$ 9.0, the optimal dose was chosen primarily based on the COD removal and the need for the lowest coagulant usage.

Table 2. Landfill leachates pretreatment results.

\begin{tabular}{cccccccc}
\hline \multirow{2}{*}{ Parameter } & \multirow{2}{*}{ Unit } & \multicolumn{2}{c}{ Acidification } & \multicolumn{2}{c}{ Coagulation at $\mathbf{p H}$ 6.0 } & \multicolumn{2}{c}{ Coagulation at $\mathbf{p H}$ 9.0 } \\
\cline { 3 - 7 } & & Value & Removal & Value & Removal & Value & Removal \\
\hline COD & $\mathrm{mg} / \mathrm{L} / \%$ & 2289 & 22.9 & 1385 & 53.3 & 1915 & 35.5 \\
$\mathrm{TOC}$ & $\mathrm{mg} / \mathrm{L} / \%$ & 824 & 22.3 & 491 & 53.7 & 793 & 25.3 \\
$\mathrm{BOD}_{5}$ & $\mathrm{mg} / \mathrm{L} / \%$ & 236 & 41.0 & 135 & 66.3 & 222 & 44.5 \\
$\mathrm{BOD}_{5} / \mathrm{TOC}$ & - & 0.286 & - & 0.275 & - & 0.280 & - \\
$\mathrm{BOD}_{5} / \mathrm{COD}$ & - & 0.103 & - & 0.097 & - & 0.116 & - \\
Ammonia & $\mathrm{mg} / \mathrm{L} / \%$ & 1291 & 3.4 & 1233 & 7.8 & 1031 & 22.9 \\
TKN & $\mathrm{mg} / \mathrm{L} / \%$ & 1301 & 7.7 & 1263 & 10.4 & 1062 & 24.7 \\
\hline
\end{tabular}

All three pretreatment methods were more effective in $\mathrm{BOD}_{5}$ in comparison with COD or TOC removal. Therefore, as a result of pretreatment, the LL susceptibility to biological treatment decreased, despite the fact that a smaller pollutant load needed to be removed.

The highest but still low efficiency of ammonium compound removal and therefore TKN removal (Table 2) was obtained by using coagulation at $\mathrm{pH}$ 9.0. This is understandable due to the higher volatility of ammonia under alkaline conditions. No significant differences between acidification and coagulation at $\mathrm{pH} 6.0$ were observed in nitrogen compound removal, but coagulation provided a slightly better effect.

\section{3. $\mathrm{Fe}^{0} / \mathrm{H}_{2} \mathrm{O}_{2}$ Process}

The results of TOC removal during the $\mathrm{Fe}^{0} / \mathrm{H}_{2} \mathrm{O}_{2}$ process after acidification at $\mathrm{pH} 3.0$ and coagulation at $\mathrm{pH} 6.0$ are shown at Figures 4 and 5, respectively. In both cases, after acidification at $\mathrm{pH}$ 3.0 and coagulation at $\mathrm{pH} 6.0$, the $\mathrm{Fe}^{0} / \mathrm{H}_{2} \mathrm{O}_{2}$ process allowed effective TOC removal. 


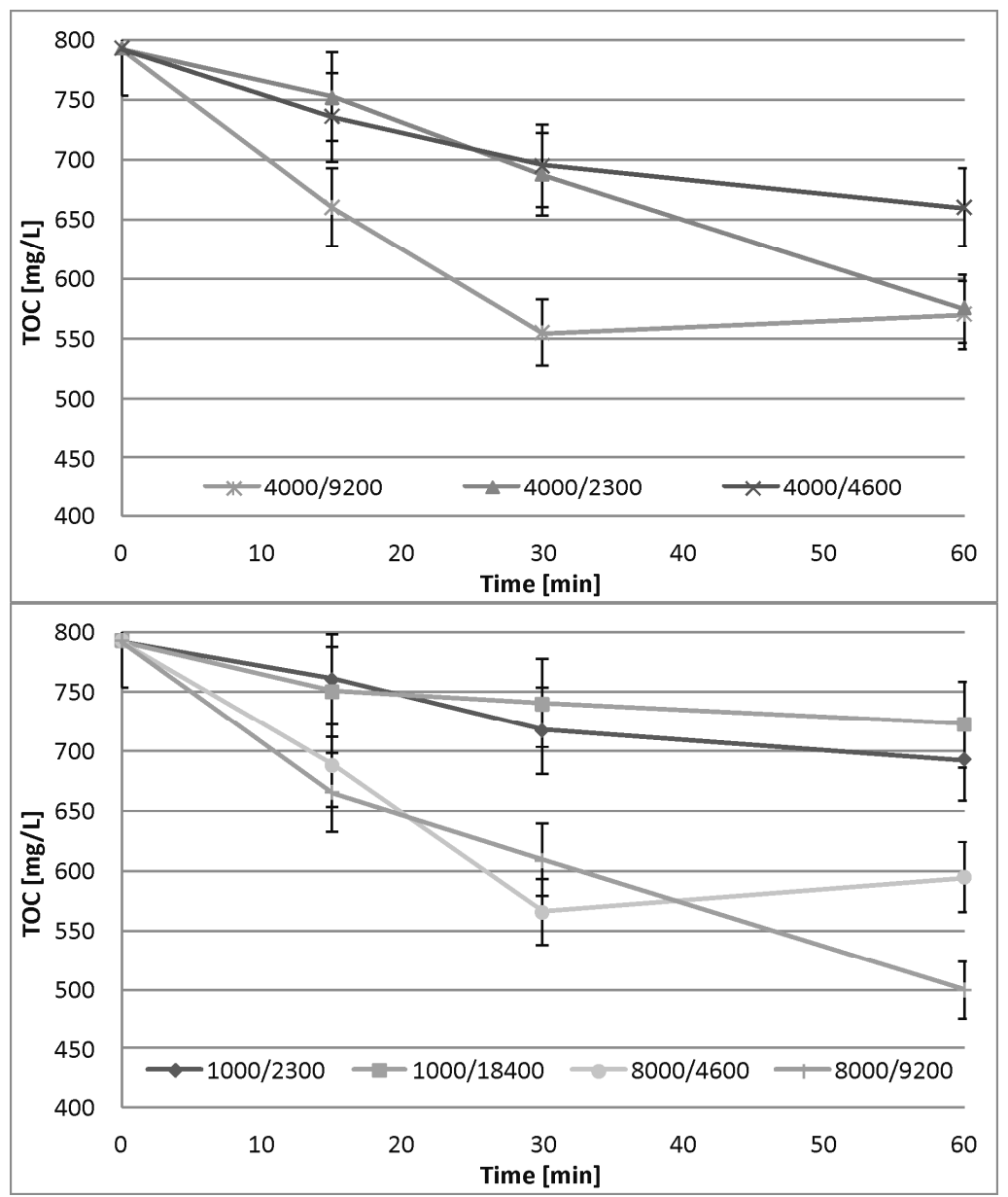

Figure 4. TOC removal during the $\mathrm{Fe}^{0} / \mathrm{H}_{2} \mathrm{O}_{2}$ process after acidification pretreatment for selected $\mathrm{Fe}^{0} / \mathrm{H}_{2} \mathrm{O}_{2}[\mathrm{mg} / \mathrm{L}]$ reagent doses.

The efficiency of the $\mathrm{Fe}^{0} / \mathrm{H}_{2} \mathrm{O}_{2}$ process after acidification increased with the reagent dose. The best efficiency was obtained for an $\mathrm{Fe}^{0} / \mathrm{H}_{2} \mathrm{O}_{2}$ reagent dose ratio of $8000 / 9200 \mathrm{mg} / \mathrm{L}$, which removed $294 \mathrm{mg} / \mathrm{L}$ to give a final value of $499 \mathrm{mg} / \mathrm{L}$. That achieves a total TOC removal of $53 \%$ by the acidification process followed by the $\mathrm{Fe}^{0} / \mathrm{H}_{2} \mathrm{O}_{2}$ process. The TOC removal over time was almost linear, except for two of the doses-8000/4600 and 4000/9200 mg/L. For them, after $60 \mathrm{~min}$, the treatment effect deteriorated.

Increasing the doses of the reagents during the $\mathrm{Fe}^{0} / \mathrm{H}_{2} \mathrm{O}_{2}$ process after coagulation at $\mathrm{pH} 6.0$ increases the effectiveness of the process. All in all, increasing the dose of $\mathrm{H}_{2} \mathrm{O}_{2}$ to $18,400 \mathrm{mg} / \mathrm{L}$ caused deterioration in the treatment effect in comparison with the lower dose. Further increasing the iron dose resulted in the necessity of increasing the agitator power to prevent solid iron sedimentation. These observations were confirmed during the experimental process after coagulation at $\mathrm{pH}$ 6.0. In this process, TOC removal was also linear over time. The efficiency of the process also increased with the iron dose. However, in $\mathrm{Fe}^{0} / \mathrm{H}_{2} \mathrm{O}_{2}$, it can be seen that increasing the $\mathrm{Fe}^{0}$ dose from 4 to $8 \mathrm{~g}$ led to only a slight increase in the treatment efficiency, especially for a $\mathrm{COD} / \mathrm{H}_{2} \mathrm{O}_{2}$ ratio other than 1:4. For all iron doses, a COD $/ \mathrm{H}_{2} \mathrm{O}_{2}$ ratio of $1: 4$ provided the best treatment effects. Because of this, 8000/5540 mg/L $\mathrm{Fe}^{0} / \mathrm{H}_{2} \mathrm{O}_{2}$ reagent doses could be considered optimal, providing a TOC decrease to $268 \mathrm{mg} / \mathrm{L}$ after $60 \mathrm{~min}$. That allows a total TOC removal of $75 \%$ after the coagulation processes at $\mathrm{pH} 6.0$ followed by the $\mathrm{Fe}^{0} / \mathrm{H}_{2} \mathrm{O}_{2}$ process. Based on the results, it can be expected that extending the treatment time would increase the efficiency of the treatment process.

As a result of the $\mathrm{Fe}^{0} / \mathrm{H}_{2} \mathrm{O}_{2}$ process, not only TOC was removed. After coagulation followed by the $\mathrm{Fe}^{0} / \mathrm{H}_{2} \mathrm{O}_{2}$ process at optimal reagent doses of $8000 / 5540 \mathrm{mg} / \mathrm{L}, \mathrm{COD}$ and $\mathrm{BOD}_{5}$ reached 755 and 
$327 \mathrm{mg} / \mathrm{L}$, respectively. The $\mathrm{BOD}_{5} / \mathrm{COD}$ ratio-a factor that determines biodegradability-increased to 0.433 , allowing LL to be considered biodegradable. Also, humic and other compounds with complex structures, as a result of the radical oxidation process, were oxidized to simpler compounds that could more easily undergo processes of biodegradation.

TNK removal was not effective. After the optimal reagent dose was applied, TKN decreased to $987 \mathrm{mg} / \mathrm{L}$ (28.8 \% removal). However, leachates, even after the initial treatment, must be subjected to biological treatment.

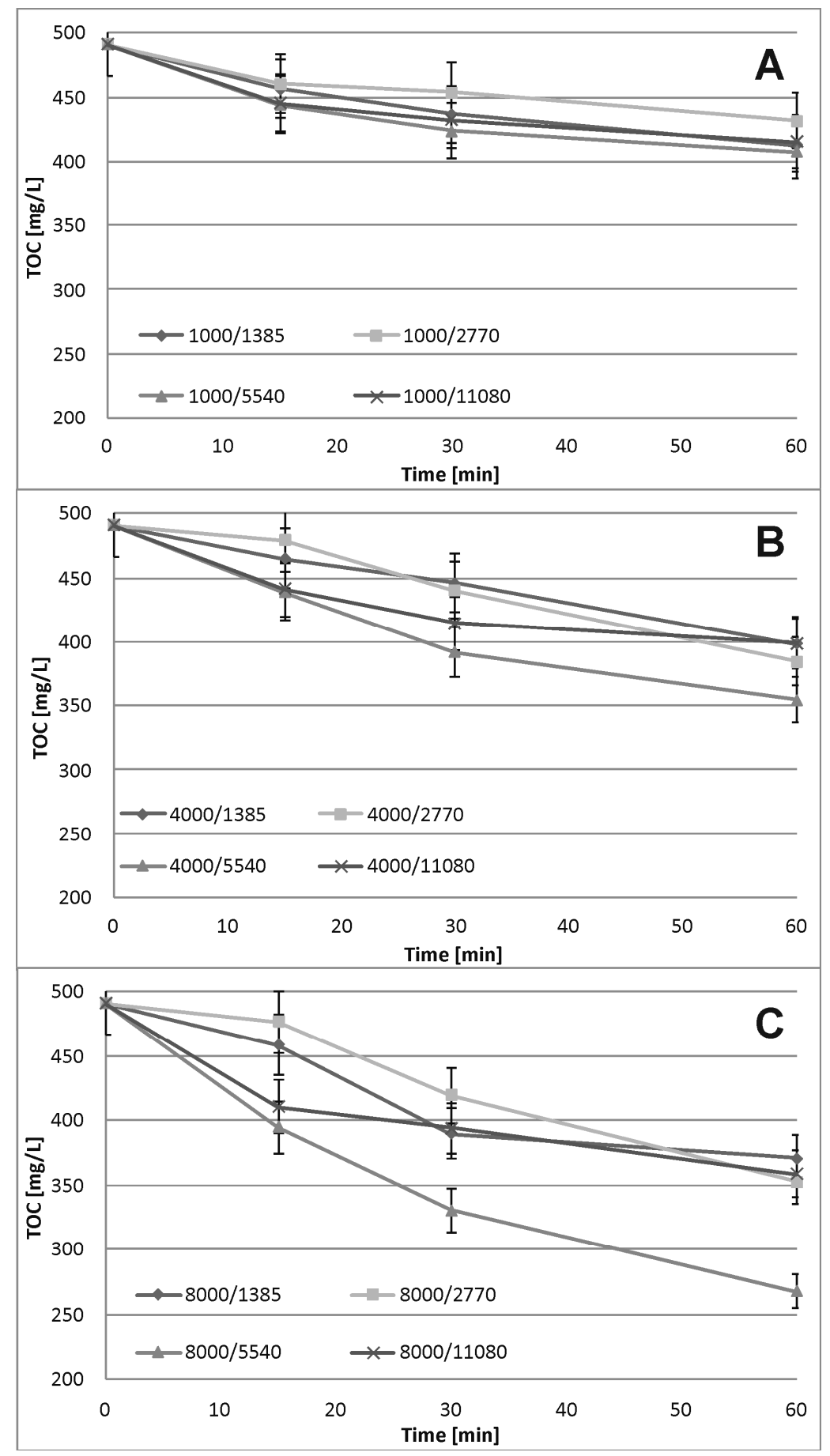

Figure 5. TOC removal during the $\mathrm{Fe}^{0} / \mathrm{H}_{2} \mathrm{O}_{2}$ process after coagulation at $\mathrm{pH} 6.0$ as pretreatment for selected $\mathrm{Fe}^{0} / \mathrm{H}_{2} \mathrm{O}_{2}[\mathrm{mg} / \mathrm{L}]$ reagent doses. 
An attempt was made to increase the efficiency of the $\mathrm{Fe}^{0} / \mathrm{H}_{2} \mathrm{O}_{2}$ process by supporting it with ultrasound and UV radiation. The results of the enhanced processes are shown at Figure 6. It was observed that both of the enhancements provided process efficiency deterioration.

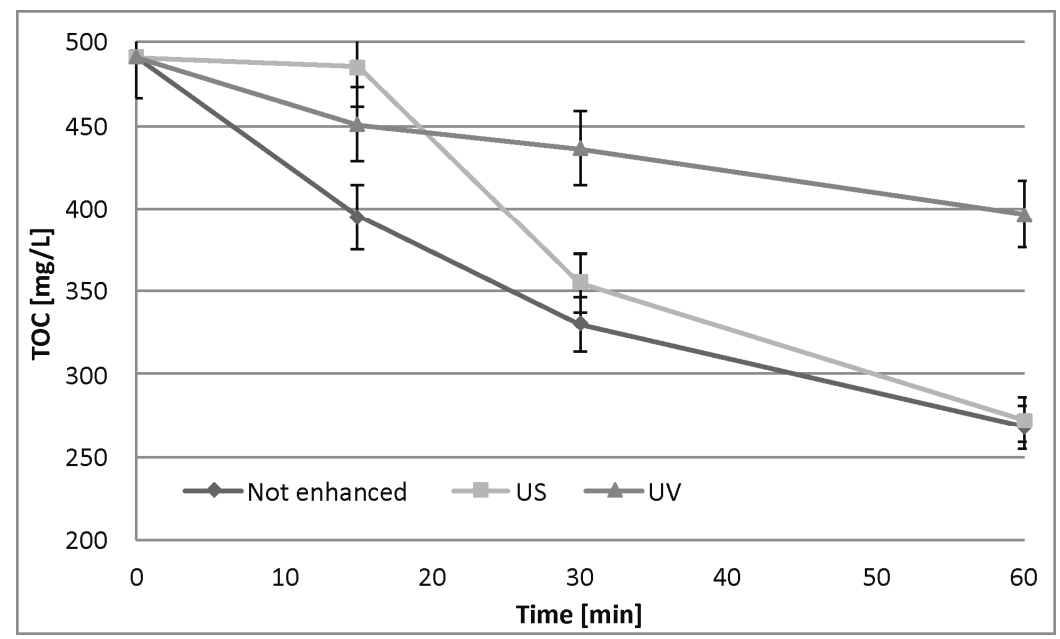

Figure 6. TOC removal during the enhanced $\mathrm{Fe}^{0} / \mathrm{H}_{2} \mathrm{O}_{2}$ process after coagulation at $\mathrm{pH} 6.0$ as pretreatment for $8000 / 5540 \mathrm{mg} / \mathrm{L} \mathrm{Fe}^{0} / \mathrm{H}_{2} \mathrm{O}_{2}$ reagent doses.

\subsection{Statistical Analysis}

A statistical analysis was done for the $\mathrm{Fe}^{0} / \mathrm{H}_{2} \mathrm{O}_{2}$ process. The correlation results between the factors (Table S1) are summarized in Table 3.

Table 3. Correlation factors for the $\mathrm{Fe}^{0} / \mathrm{H}_{2} \mathrm{O}_{2}$ process.

\begin{tabular}{ccccccccccc}
\hline \multirow{2}{*}{ Parameters } & \multicolumn{3}{c}{ After Acidification at pH $\mathbf{3 . 0}$} & \multicolumn{3}{c}{ After Coagulation at pH 6.0 } \\
\cline { 3 - 10 } & & TOC & Time & $\begin{array}{c}\text { Mass } \\
\text { Ratio }\end{array}$ & $\begin{array}{c}\text { Iron } \\
\text { Mass }\end{array}$ & TOC & Time & $\begin{array}{c}\text { Mass } \\
\text { Ratio }\end{array}$ & $\begin{array}{c}\text { Iron } \\
\text { Mass }\end{array}$ \\
\hline \multirow{3}{*}{$\begin{array}{c}\text { Pearson } \\
\text { Correlation }\end{array}$} & TOC & 1.000 & -0.793 & 0.060 & -0.388 & 1.000 & -0.797 & -0.113 & -0.306 \\
& Mass ratio & 0.060 & 0.001 & 1.000 & -0.200 & -0.113 & 0.000 & 1.000 & 0.000 \\
& Iron mass & -0.388 & -0.009 & -0.200 & 1.000 & -0.306 & 0.000 & 0.000 & 1.000 \\
\hline \multirow{3}{*}{ Significance } & TOC & - & 0.000 & 0.385 & 0.025 & - & 0.000 & 0.223 & 0.017 \\
(1-tailed) & Time & 0.000 & - & 0.498 & 0.483 & 0.000 & - & 0.500 & 0.500 \\
& Mass ratio & 0.385 & 0.498 & - & 0.164 & 0.223 & 0.500 & - & 0.500 \\
& Iron mass & 0.025 & 0.483 & 0.164 & - & 0.017 & 0.500 & 0.500 & - \\
\hline
\end{tabular}

The linear regression results are summarized in Table 4 . Based on the linear regression coefficients, the TOC concentration can be expressed as (4) and (5) for $\mathrm{Fe}^{0} / \mathrm{H}_{2} \mathrm{O}_{2}$ process after acidification at pH 3.0 and after coagulation at $\mathrm{pH} 6.0$, respectively.

$$
\begin{gathered}
\mathrm{Y}(\mathrm{TOC})=827.545-2.798 \times \text { Time }-12.028 \times \text { Iron mass } \\
\mathrm{Y}(\mathrm{TOC})=511.879-1.810 \times \text { Time }-2.122 \times \text { Mass ratio }-5.386 \times \text { Iron mass }
\end{gathered}
$$

In order to find the importance for each factor on TOC concentration, the optimal scaling test was applied. The importance percentages for each parameter after acidification were $51.5 \%, 43.8 \%$, and $4.7 \%$ for time, iron mass, and the mass ratio, respectively (Table S2). These percentages also confirm that the mass ratio could be excluded from the model. The time, iron mass and mass ratio importance percentages after coagulation were $62.5 \%, 22.5 \%$, and $14.9 \%$, respectively (Table S3). It can be recognized that the importance arrangement is similar to that of the acidification one. 
The description and model developed describes this unique sample only. The statistical model allows some important parameters to be predicted, for example, which parameters are important and sensitive for wastewater parameter changes and which are not. What is surprising, in the case of this leachate sample, is that not all parameters that should be important from a chemical or, in another words, "technological" point of view, are important from a statistical point of view.

Table 4. Regression coefficients for the $\mathrm{Fe}^{0} / \mathrm{H}_{2} \mathrm{O}_{2}$ process. Dependent variable: TOC.

\begin{tabular}{|c|c|c|c|c|c|c|c|c|}
\hline \multirow{2}{*}{\multicolumn{2}{|c|}{ Model }} & \multicolumn{2}{|c|}{ Unstd. Coef. } & \multirow{2}{*}{$\frac{\text { Std. Coef. }}{\text { Beta }}$} & \multirow{2}{*}{$\mathbf{t}$} & \multirow{2}{*}{ Sig. } & \multirow{2}{*}{$\mathbf{R}$} & \multirow{2}{*}{$\mathbf{R}^{2}$} \\
\hline & & Factors & Std. Error & & & & & \\
\hline \multirow{3}{*}{$\begin{array}{c}\text { After } \\
\text { acidification }\end{array}$} & Constant & 827.545 & 17.066 & - & 48.492 & 0.00 & \multirow{3}{*}{0.886} & \multirow{3}{*}{0.784} \\
\hline & Time & -2.798 & 0.340 & -0.796 & -8.220 & 0.00 & & \\
\hline & Iron mass & -12.028 & 2.948 & -0.395 & -4.080 & 0.00 & & \\
\hline \multirow{4}{*}{$\begin{array}{c}\text { After } \\
\text { coagulation }\end{array}$} & Constant & 511.879 & 9.960 & - & 51.392 & 0.00 & \multirow{4}{*}{0.861} & \multirow{4}{*}{0.741} \\
\hline & Time & -1.810 & 0.174 & -0.797 & -10.391 & 0.00 & & \\
\hline & Mass ratio & -2.122 & 1.442 & -0.113 & -1.472 & 0.148 & & \\
\hline & Iron mass & -5.386 & 1.348 & -0.306 & -3.995 & 0.00 & & \\
\hline
\end{tabular}

\section{5. $\mathrm{Fe}^{0} / \mathrm{H}_{2} \mathrm{O}_{2}$ Process Kinetics}

Usually $\mathrm{Fe}^{0} / \mathrm{H}_{2} \mathrm{O}_{2}$ process kinetics is described as first-order or second-order $[49,50]$. This approach was not successful in the case of pretreated landfill leachates. Application of the firstand second-order reaction equations resulted in low correlation coefficients (data not shown). Much better correlation coefficients were obtained using the empirical model (10), as shown in Tables 5 and 6 .

Table 5. Parameters of the empirical kinetic equation for $\mathrm{Fe}^{0} / \mathrm{H}_{2} \mathrm{O}_{2}$ process after acidification at $\mathrm{pH}$ 3.0.

\begin{tabular}{cccccc}
\hline Dose $[\mathbf{m g} / \mathbf{L}]$ & $\mathbf{a}$ & $\mathbf{m}$ & $\mathbf{n}$ & $\mathbf{K}$ & $\mathbf{R}^{\mathbf{2}}$ \\
\hline $1000 / 2300$ & 0.009605 & -0.313 & 0.687 & 0.013982 & 0.977 \\
$1000 / 18400$ & 0.009581 & -0.720 & 0.280 & 0.034218 & 0.952 \\
$4000 / 2300$ & 0.010183 & 0.003 & 1.003 & 0.010153 & 0.995 \\
$4000 / 4600$ & 0.016787 & -0.496 & 0.504 & 0.033307 & 0.999 \\
$4000 / 9200$ & 0.039705 & -0.647 & 0.353 & 0.112478 & 0.764 \\
$8000 / 4600$ & 0.034112 & -0.564 & 0.436 & 0.078238 & 0.712 \\
$8000 / 9200$ & 0.037883 & -0.476 & 0.524 & 0.072295 & 0.951 \\
\hline
\end{tabular}

Table 6. Parameters of the empirical kinetic equation for $\mathrm{Fe}^{0} / \mathrm{H}_{2} \mathrm{O}_{2}$ process after coagulation with $\mathrm{FeCl}_{3}$ at $\mathrm{pH} 6.0$.

\begin{tabular}{cccccc}
\hline Dose $[\mathbf{m g} / \mathbf{L}]$ & $\mathbf{a}$ & $\mathbf{m}$ & $\mathbf{n}$ & $\mathbf{K}$ & $\mathbf{R}^{\mathbf{2}}$ \\
\hline $1000 / 1385$ & 0.016031 & -0.523 & 0.477 & 0.033608 & 0.993 \\
$1000 / 2770$ & 0.012431 & -0.636 & 0.364 & 0.034150 & 0.862 \\
$1000 / 5540$ & 0.019875 & -0.654 & 0.346 & 0.057441 & 1.000 \\
$1000 / 11080$ & 0.017661 & -0.704 & 0.296 & 0.059666 & 0.978 \\
$4000 / 1385$ & 0.011541 & -0.273 & 0.727 & 0.015875 & 0.951 \\
$4000 / 2770$ & 0.004156 & 0.280 & 1.280 & 0.003247 & 0.998 \\
$4000 / 5540$ & 0.025883 & -0.402 & 0.598 & 0.043283 & 0.997 \\
$4000 / 11080$ & 0.022269 & -0.629 & 0.371 & 0.060025 & 0.991 \\
$8000 / 1385$ & 0.016244 & -0.178 & 0.822 & 0.019762 & 0.930 \\
$8000 / 2770$ & 0.004718 & 0.363 & 1.363 & 0.003462 & 0.991 \\
$8000 / 5540$ & 0.049371 & -0.433 & 0.567 & 0.087074 & 0.998 \\
$8000 / 11080$ & 0.032128 & -0.697 & 0.303 & 0.106034 & 0.924 \\
\hline
\end{tabular}

The rate of the $\mathrm{Fe}^{0} / \mathrm{H}_{2} \mathrm{O}_{2}$ process is much more difficult to describe, as metallic iron dissolution, chemical oxidation, coprecipitation and coagulation affect the overall treatment efficiency. Each of these processes is at least partially independent of the others, and they are sometimes contradictory. 
This sometimes results in a decrease in the effectiveness of the process over time and deterioration of the correlation parameters. This can clearly be seen for high reagent doses in the process after acidification (Table 5 and Figure 6).

\section{Discussion}

\subsection{Raw Landfill Leachate Characteristics}

The analyzed samples have similar characteristics to others collected from Polish landfills $[17,49,51,52]$.

\subsection{Pretreatment}

The acidification efficiency is strongly $\mathrm{pH}$-dependent. Based on the literature review, it was determined that the highest was at $\mathrm{pH} 2.0$ and this decreased with an increasing $\mathrm{pH}$ [49]. As a result of acidification, the dissociation of humic acids is reversed, decreasing their solubility. As a result, they are removed from the leachate in the form of a precipitate [17].

Acidification to $\mathrm{pH} 3.0$ was chosen as a compromise between the efficiency of the process, the necessity of using a large amount of acid, and the convenience of further treatment processes (no need for $\mathrm{pH}$ adjustment). It was observed that during sedimentation, the sediment particles enlarged. The advantage of this pretreatment method is simplicity; there is no need to use expensive reagents and complicated processes. It occurs exactly at this $\mathrm{pH}$ which is optimal for the $\mathrm{Fe}^{0} / \mathrm{H}_{2} \mathrm{O}_{2}$ process. The disadvantage of the process is the sludge formation and considerable time consumption $-24 \mathrm{~h}$ is required for sedimentation.

The mechanism of $\mathrm{FeCl}_{3}$ coagulation varies depending on the $\mathrm{pH}$ of the process. It is assumed that at $\mathrm{pH} 6.0$, the neutralization of colloid charge prevails, while at $\mathrm{pH} 9.0$, an important mechanism is adsorption on the created hydroxide surface.

It could be also concluded that the effect of using acidification is comparable to coagulation at $\mathrm{pH}$ 9.0. Comparing all the three pretreatment methods, it could be concluded that coagulation at $\mathrm{pH} 6.0$ was the best method, in terms of organic compounds removal.

The coagulation process is more complicated than acidification; it requires more reagents. On the other hand, the sedimentation time for coagulation is much shorter than in the case of acidification.

Based on pretreatment results, two processes were chosen to be used before the $\mathrm{Fe}^{0} / \mathrm{H}_{2} \mathrm{O}_{2}$ processes. Coagulation at $\mathrm{pH} 6.0$ was chosen, because of the best treatment effects in terms of organics removal. Also, acidification was chosen, because of its simplicity and the lack of need for further $\mathrm{pH}$ adjustment. Coagulation at $\mathrm{pH} 9.0$ was eliminated because of two reasons. The first one was the complication with the $\mathrm{pH}$ adjustment: from 7.65 to 9.0, then finally to 3.0. That caused acid/base reagent consumption and an additional salinity increase. The second one was the similar treatment effect to acidification at $\mathrm{pH}$ 3.0. The results obtained are in good agreement with the available literature $[9,39,52]$.

\section{3. $\mathrm{Fe}^{0} / \mathrm{H}_{2} \mathrm{O}_{2}$ Process}

As a result of hydrogen peroxide decomposition, oxygen bubbles broke up the created flocks, hindering sedimentation. Part of the flocks were disintegrated and permanently suspended in the solution. A similar effect but on a smaller scale was observed in all experiments using large doses of hydrogen peroxide. In the LL, after the process, there was a large excess of unreacted hydrogen peroxide (not determined in the experiment). However, decreasing the dose to reduce the hydrogen peroxide excess resulted in deterioration in the treatment effectiveness.

Due to the high $\mathrm{BOD}_{5} / \mathrm{COD}$ ratio, it can be assumed that effective removal of organic and nitrogen compounds will be possible $[34,37,38]$. Also, other studies suggest that advanced oxidation usage increases biodegradability $[14,17]$. Coagulation with $\mathrm{FeCl}_{3}$ at $\mathrm{pH} 6.0$, coupled with the $\mathrm{Fe}^{0} / \mathrm{H}_{2} \mathrm{O}_{2}$ 
process, proved to have similar efficiency to other processes tested in the available literature, including electrochemical $[11,20,36]$ and advanced oxidation $[15-17,19,21,25]$ treatments.

Although it is generally agreed, that a highly saline matrix generates a radical scavenging effect, it also has been proven that the $\mathrm{Fe}^{0} / \mathrm{H}_{2} \mathrm{O}_{2}$ process is effective for such a matrix. This has been assessed not only for LL, but also for flue gas desulfurization [48], pharmaceutic [53] wastewater, and hydraulic fracturing flow back fluid [54].

For the $\mathrm{Fe}^{0} / \mathrm{H}_{2} \mathrm{O}_{2}$ process supported with ultrasound and UV radiation, the obtained results contrast with those of Chen et al. [10], who proved that microwave or heat application enhances the efficiency of the $\mathrm{Fe}^{0} / \mathrm{H}_{2} \mathrm{O}_{2}$ process. Heating and microwaves accelerate the thermal motion of molecules and, as a consequence, the Fenton reaction rate increases to some extent. When UV and US were applied, an increase in temperature was not observed. The obtained results also contrast with process improvement concepts-UV and US should strengthen the mechanisms of radical generation [55]. In the case of UV usage, the treatment result increased with the iron dose, but it was weaker without UV radiation. This could be may be associated with the formation of stable complexes that bind iron ions under the influence of light. A similar effect was observed in the case of US application. As it was impossible to magnetically stir the US samples, mechanical stirring with the same stirring speed was applied. Changing the stirring method from magnetic into a mechanic one could result in a decrease in process efficiency because of the paramagnetic properties of oxygen. Under the magnetic stirrer, the magnetic field increased the treatment efficiency [56,57]. It was also proved that radical generation is higher in oxic conditions [50], with a bigger amount of dissolved oxygen [58], or with more intensive stirring [53]. The presented reasons for decreasing the efficiency of the conducted process are only hypotheses, not confirmed speculations, and require further confirmation. Based on the obtained results, it could be concluded that process enhancements with UV and US are not recommended, as they do not provide treatment efficiency, and only cause increased complications and costs of the process.

\subsection{Statistical Analysis}

TOC is strongly correlated to the time and iron mass. The mass ratio-TOC correlation is very weak. Moreover, it is noticeable that the correlation between the independent factors is not significant. The interaction between the independent factor will not affect the TOC regression. Because of this, it was confirmed that there is no need for application of a more complex model than linear regression.

It can be seen (Table 4) that the $\mathrm{R}^{2}$ values for the two models are high, and the models are well fitted to the data. In the $\mathrm{Fe}^{0} / \mathrm{H}_{2} \mathrm{O}_{2}$ process after acidification at $\mathrm{pH}$ 3.0, the mass ratio significance was 0.855 , which higher than $5 \%$. So, it was excluded from the model.

It can be concluded that the most important factor for the $\mathrm{Fe}^{0} / \mathrm{H}_{2} \mathrm{O}_{2}$ process is time. This can also be confirmed from the high negative correlation between the time and the TOC concentration, even though it can be seen from Equations (4) and (5) that the highest removal can be due to an increase in iron mass. This is due to the unit step difference between the time and iron mass. The time was duplicated while the iron mass amount was four time more for each step.

\subsection{Possibility of Practical Application of The Process and Cost Consideration}

The Fenton process and its modifications have been known for a very long time, but they have mainly been tested on the laboratory scale and sometimes in pilot studies. There are very few installations operating on an industrial scale, especially when compared to installations using conventional technologies such as coagulation or activated sludge. To our knowledge, in Poland, there are only a few Fenton process installations at the full technical scale, and they are very young, not older than 10 years. The studied processes are not conventional for wastewater treatment. Typical analyzed coasts are related to electricity and reagent consumption [59]. It is described in scientific articles, not as a practical implementation. As is well known, costs change according to plant size, type 
of reagents, energy demand, etc. For each country, the legal regulations are different, as are labor or investment costs. Because of this, it is hard to predict the total treatment costs.

Another challenge that need to be solved is the transfer from the laboratory scale into the industrial one, which most likely decreases the process effectiveness. As a coagulation reactor, leachate storage tanks could be used. The tanks for sedimentation, the $\mathrm{Fe}^{0} / \mathrm{H}_{2} \mathrm{O}_{2}$ process, and final sedimentation also need to be built. Usually, landfills have enough space and the possibility for their construction.

Some costs will be generated by the reagents, but the reagents used for coagulation and $\mathrm{pH}$ adjustment are cheap and readily available. In the case of metallic iron, it does not have to be used in the form of chemically pure metal. Metallurgical waste or steel shots could be used to decrease costs. After the $\mathrm{Fe}^{0} / \mathrm{H}_{2} \mathrm{O}_{2}$ process, residual solid catalyst could be reused. The material can be separated from treated LL in two ways: electromagnetically or through sedimentation.

Now, AOPs are more expensive than conventional treatment. Because of their high predicted installation costs in Poland for current legal regulations regarding labor and investment costs, unfortunately, we can see no chance for this research to have practical implementation.

\section{Conclusions}

The use of a combined treatment process including coagulation with an iron-based coagulant or acidification followed by the $\mathrm{Fe}^{0} / \mathrm{H}_{2} \mathrm{O}_{2}$ process was shown to be an effective landfill leachate treatment. Coagulation is more effective than acidification, allowing larger pollutant load removal and decreasing the reagent doses used in the $\mathrm{Fe}^{0} / \mathrm{H}_{2} \mathrm{O}_{2}$ process. Pretreatment efficiency: coagulation at $\mathrm{pH} 6.0>>$ coagulation at $\mathrm{pH} 9.0>$ acidification at $\mathrm{pH}$ 3.0. The $\mathrm{Fe}^{0} / \mathrm{H}_{2} \mathrm{O}_{2}$ process was more effective after coagulation at $\mathrm{pH} 6.0$ than with the one after acidification at $\mathrm{pH}$ 3.0. It was observed that increasing the reagent doses increased treatment efficiency. However, further increasing the doses of reagents is economically unjustified. Under optimal conditions, after coagulation with $\mathrm{FeCl}_{3}$ at an $\mathrm{Fe}^{3+}$ dose of $1000 \mathrm{mg} / \mathrm{L}$, the $\mathrm{Fe}^{0} / \mathrm{H}_{2} \mathrm{O}_{2}$ process with $\mathrm{Fe}^{0} / \mathrm{H}_{2} \mathrm{O}_{2}$ reagent doses of $8000 / 5540 \mathrm{mg} / \mathrm{L}$ decreased TOC from 1061 to $268 \mathrm{mg} / \mathrm{L}$ (75\% TOC removal) after a process time of $60 \mathrm{~min}$. Furthermore, its susceptibility to biodegradation, expressed as the $\mathrm{BOD}_{5} / \mathrm{COD}$ ratio, increased. Under optimal conditions, this parameter reached 0.43 , from an initial value of 0.13 , allowing leachates to be considered to be susceptible to biodegradation. As a result of the oxidation step during the $\mathrm{Fe}^{0} / \mathrm{H}_{2} \mathrm{O}_{2}$ process, persistent compounds were transformed to more vulnerable ones. The kinetics of the $\mathrm{Fe}^{0} / \mathrm{H}_{2} \mathrm{O}_{2}$ process is complicated. A simple approach assuming first- or second-order kinetics was not effective. The $\mathrm{Fe}^{0} / \mathrm{H}_{2} \mathrm{O}_{2}$ process kinetics was successfully described with the empirical equation $\mathrm{d}[\mathrm{TOC}] / \mathrm{dt}=$ $-\mathrm{a} \cdot[\mathrm{TOC}] \cdot \mathrm{t}$ ', where ' $\mathrm{t}$ ' corresponds to time and ' $\mathrm{a}$ ' and ' $\mathrm{m}$ ' are constants that depend on the initial reagent concentrations.

Supplementary Materials: The following are available online at http:/ /www.mdpi.com/2073-4441/11/2/194/ s1, Table S1. The factors of the different performed experiments, Table S2. Correlations and Tolerance after acidification, Dependent Variable: TOC, Table S3. Correlations and Tolerance for coagulation, Dependent Variable: TOC.

Author Contributions: Author contributions are as follows. Conceptualization and Methodology: J.B. and P.M.; Laboratory Work: All Authors; Writing and Original Draft Preparation: All Authors. Statistical Analysis: B.E.-K.

Funding: This research received no external funding.

Acknowledgments: The authors thank Hepure for providing ZVI Ferox Target samples as research material.

Conflicts of Interest: The authors declare no conflicts of interest.

\section{References}

1. Eurostat. Municipal Waste Statistics. Available online: https://ec.europa.eu/eurostat/statistics-explained/ index.php/Municipal_waste_statistics (accessed on 15 December 2018). 
2. Augusto, P.A.; Castelo-Grande, T.; Merchan, L.; Estevez, A.M.; Quintero, X.; Barbosa, D. Landfill Leachate Treatment by Sorption in Magnetic Particles: Preliminary Study. Sci. Total Environ. 2019, 648, 636-668. [CrossRef] [PubMed]

3. Qi, C.; Huang, J.; Wang, B.; Deng, S.; Wang, Y.; Yu, G. Contaminants of Emerging Concern in Landfill Leachate in China: A Review. Emerg. Contam. 2018. [CrossRef]

4. Martins, R.C.; Lopes, D.V.; Quina, M.J.; Quinta-Ferreira, R.M. Treatment Improvement of Urban Landfill Leachates by Fenton-like Process Using ZVI. Chem. Eng. J. 2012, 192, 219-225. [CrossRef]

5. Bhatt, A.H.; Karanjekar, R.V.; Altouqi, S.; Sattler, M.L.; Hossain, M.D.S.; Chen, V.P. Estimating Landfill Leachate BOD and COD Based on Rainfall, Ambient Temperature, and Waste Composition: Exploration of a MARS Statistical Approach. Environ. Technol. Innov. 2017, 8, 1-16. [CrossRef]

6. Moody, C.M.; Townsend, T.G. A Comparison of Landfill Leachates Based on Waste Composition. Waste Manag. 2017, 63, 267-274. [CrossRef] [PubMed]

7. Zhao, R.; Gupta, A.; Novak, J.T.; Goldsmith, C.D. Evolution of Nitrogen Species in Landfill Leachates under Various Stabilization States. Waste Manag. 2017, 69, 225-231. [CrossRef] [PubMed]

8. Mohammad-pajooh, E.; Turcios, A.E.; Cuff, G.; Weichgrebe, D.; Rosenwinkel, K.H.; Vedenyapina, M.D.; Sharifullina, L.R. Removal of Inert COD and Trace Metals from Stabilized Landfill Leachate by Granular Activated Carbon (GAC) Adsorption. J. Environ. Manag. 2018, 228, 189-196. [CrossRef]

9. Bilardi, S.; Calabrò, P.S.; Rosa, G.; Moraci, N. Selective Removal of Heavy Metals from Landfill Leachate by Reactive Granular Filters. Sci. Total Environ. 2018, 644, 335-341. [CrossRef]

10. Chen, W.; Zhang, A.; Gu, Z.; Li, Q. Enhanced Degradation of Refractory Organics in Concentrated Landfill Leachate by $\mathrm{Fe}^{0} / \mathrm{H}_{2} \mathrm{O}_{2}$ coupled with Microwave Irradiation. Chem. Eng. J. 2018, 354, 680-691. [CrossRef]

11. Wang, Z.; Li, J.; Tan, W.; Wu, X.; Lin, H.; Zhang, H. Removal of COD from Landfill Leachate by Advanced Fenton Process Combined with Electrolysis. Sep. Purif. Technol. 2018, 208, 3-11. [CrossRef]

12. Guo, R.; Meng, Q.; Zhang, H.; Zhang, X.; Li, B.; Cheng, Q.; Cheng, X. Construction of $\mathrm{Fe}_{2} \mathrm{O}_{3} / \mathrm{Co}_{3} \mathrm{O}_{4} /$ Exfoliated Graphite Composite and Its High Efficient Treatment of Landfill Leachate by Activation of Potassium Persulfate. Chem. Eng. J. 2019, 355, 952-962. [CrossRef]

13. Soubh, A.M.; Baghdadi, M.; Abdoli, M.A.; Aminzadeh, B. Zero-Valent Iron Nanofibers (ZVINFs) Immobilized on the Surface of Reduced Ultra-Large Graphene Oxide (RULGO) as a Persulfate Activator for Treatment of Landfill Leachate. J. Environ. Chem. Eng. 2018, 6, 6568-6579. [CrossRef]

14. Da Costa, F.M.; Daflon, S.D.A.; Bila, D.M.; da Fonseca, F.V.; Campos, J.C. Evaluation of the Biodegradability and Toxicity of Landfill Leachates after Pretreatment Using Advanced Oxidative Processes. Waste Manag. 2018, 76, 606-613. [CrossRef] [PubMed]

15. Nakhate, P.H.; Patil, H.G.; Marathe, K.V. Intensification of Landfill Leachate Treatment by Advanced Fenton Process Using Classical and Statistical Approach. Chem. Eng. Process. Process Intensif. 2018, 133, 148-159. [CrossRef]

16. Silveira, J.E.; Zazo, J.A.; Pliego, G.; Casas, J.A. Landfill Leachate Treatment by Sequential Combination of Activated Persulfate and Fenton Oxidation. Waste Manag. 2018, 81, 220-225. [CrossRef] [PubMed]

17. Naumczyk, J.; Prokurat, I.; Marcinowski, P. Landfill Leachates Treatment by $\mathrm{H}_{2} \mathrm{O}_{2} / \mathrm{UV}, \mathrm{O}_{3} / \mathrm{H}_{2} \mathrm{O}_{2}$, Modified Fenton, and Modified Photo-Fenton Methods. Int. J. Photoenergy 2012, 2012. [CrossRef]

18. Baiju, A.; Gandhimathi, R.; Ramesh, S.T.; Nidheesh, P.V. Combined Heterogeneous Electro-Fenton and Biological Process for the Treatment of Stabilized Landfill Leachate. J. Environ. Manag. 2018, 210, 328-337. [CrossRef]

19. Sruthi, T.; Gandhimathi, R.; Ramesh, S.T.; Nidheesh, P.V. Stabilized Landfill Leachate Treatment Using Heterogeneous Fenton and Electro-Fenton Processes. Chemosphere 2018, 210, 38-43. [CrossRef]

20. Cui, Y.H.; Xue, W.J.; Yang, S.Q.; Tu, J.L.; Guo, X.L.; Liu, Z.Q. Electrochemical/Peroxydisulfate/Fe ${ }^{3+}$ treatment $^{2}$ of Landfill Leachate Nanofiltration Concentrate after Ultrafiltration. Chem. Eng. J. 2018, 353, $208-217$. [CrossRef]

21. Dia, O.; Drogui, P.; Buelna, G.; Dubé, R. Hybrid Process, Electrocoagulation-Biofiltration for Landfill Leachate Treatment. Waste Manag. 2018, 75, 391-399. [CrossRef]

22. Huda, N.; Raman, A.A.A.; Bello, M.M.; Ramesh, S. Electrocoagulation Treatment of Raw Landfill Leachate Using Iron-Based Electrodes: Effects of Process Parameters and Optimization. J. Environ. Manag. 2017, 204, 75-81. [CrossRef] [PubMed] 
23. Klauck, C.R.; Giacobbo, A.; Altenhofen, C.G.; Silva, L.B.; Meneguzzi, A.; Bernardes, A.M.; Rodrigues, M.A.S. Toxicity Elimination of Landfill Leachate by Hybrid Processing of Advanced Oxidation Process and Adsorption. Environ. Technol. Innov. 2017, 8, 246-255. [CrossRef]

24. Zhang, W.; Li, X.; Yang, Q.; Wang, D.; Wu, Y.; Zhu, X.; Wei, J.; Liu, Y.; Hou, L.; Chen, C. Pretreatment of Landfill Leachate in Near-Neutral PH Condition by Persulfate Activated Fe-C Micro-Electrolysis System. Chemosphere 2019, 216, 749-756. [CrossRef] [PubMed]

25. Poblete, R.; Oller, I.; Maldonado, M.I.; Cortes, E. Improved Landfill Leachate Quality Using Ozone, UV Solar Radiation, Hydrogen Peroxide, Persulfate and Adsorption Processes. J. Environ. Manag. 2019, 232, 45-51. [CrossRef] [PubMed]

26. Xu, Q.; Siracusa, G.; Di Gregorio, S.; Yuan, Q. COD Removal from Biologically Stabilized Landfill Leachate Using Advanced Oxidation Processes (AOPs). Process Saf. Environ. Prot. 2018, 120, 278-285. [CrossRef]

27. Nazimudheen, G.; Roy, K.; Sivasankar, T.; Moholkar, V.S. Mechanistic Investigations in Ultrasonic Pretreatment and Anaerobic Digestion of Landfill Leachates. J. Environ. Chem. Eng. 2018, 6, 1690-1701. [CrossRef]

28. Saleem, M.; Spagni, A.; Alibardi, L.; Bertucco, A.; Lavagnolo, M.C. Assessment of Dynamic Membrane Filtration for Biological Treatment of Old Landfill Leachate. J. Environ. Manag. 2018, 213, 27-35. [CrossRef]

29. Montusiewicz, A.; Bis, M.; Pasieczna-Patkowska, S.; Majerek, D. Mature Landfill Leachate Utilization Using a Cost-Effective Hybrid Method. Waste Manag. 2018, 76, 652-662. [CrossRef]

30. Chang, H.; Quan, X.; Zhong, N.; Zhang, Z.; Lu, C.; Li, G.; Cheng, Z.; Yang, L. High-Efficiency Nutrients Reclamation from Landfill Leachate by Microalgae Chlorella Vulgaris in Membrane Photobioreactor for Bio-Lipid Production. Bioresour. Technol. 2018, 266, 374-381. [CrossRef]

31. Guan, Y.; Zhou, J.; Fu, X.; Zhao, Y.; Luo, A.; Xu, J.; Fu, J.; Zhao, D. Effects of Long-Lasting Nitrogen and Organic Shock Loadings on an Engineered Biofilter Treating Matured Landfill Leachate. J. Hazard. Mater. 2018, 360, 536-543. [CrossRef]

32. Scandelai, A.P.J.; Cardozo Filho, L.; Martins, D.C.C.; Freitas, T.K.F.D.S.; Garcia, J.C.; Tavares, C.R.G. Combined Processes of Ozonation and Supercritical Water Oxidation for Landfill Leachate Degradation. Waste Manag. 2018, 77, 466-476. [CrossRef] [PubMed]

33. Fan, Z.; Qin, L.; Zheng, W.; Meng, Q.; Shen, C.; Zhang, G. Oscillating Membrane Photoreactor Combined with Salt-Tolerated Chlorella Pyrenoidosa for Landfill Leachates Treatment. Bioresour. Technol. 2018, 269, 134-142. [CrossRef] [PubMed]

34. Peng, W.; Pivato, A.; Lavagnolo, M.C.; Raga, R. Digestate Application in Landfill Bioreactors to Remove Nitrogen of Old Landfill Leachate. Waste Manag. 2018, 74, 335-346. [CrossRef] [PubMed]

35. Saleem, M.; Lavagnolo, M.C.; Campanaro, S.; Squartini, A. Dynamic Membrane Bioreactor (DMBR) for the Treatment of Landfill Leachate; Bioreactor's Performance and Metagenomic Insights into Microbial Community Evolution. Environ. Pollut. 2018, 243, 326-335. [CrossRef]

36. Wang, D.; Hou, H.; Hu, J.; Xu, J.; Huang, L.; Hu, S.; Liang, S.; Xiao, K.; Liu, B.; Yang, J. A Bio-Electro-Fenton System with a Facile Anti-Biofouling Air Cathode for Efficient Degradation of Landfill Leachate. Chemosphere 2019, 215, 173-181. [CrossRef] [PubMed]

37. Wu, L.; Li, Z.; Zhao, C.; Liang, D.; Peng, Y. A Novel Partial-Denitrification Strategy for Post-Anammox to Effectively Remove Nitrogen from Landfill Leachate. Sci. Total Environ. 2018, 633, 745-751. [CrossRef] [PubMed]

38. Xiong, J.; Zheng, Z.; Yang, X.; He, J.; Luo, X.; Gao, B. Mature Landfill Leachate Treatment by the MBBR Inoculated with Biocarriers from a Municipal Wastewater Treatment Plant. Process Saf. Environ. Prot. 2018, 119, 304-310. [CrossRef]

39. Yong, Z.J.; Bashir, M.J.K.; Ng, C.A.; Sethupathi, S.; Lim, J.W. A Sequential Treatment of Intermediate Tropical Landfill Leachate Using a Sequencing Batch Reactor (SBR) and Coagulation. J. Environ. Manag. 2018, 205, 244-252. [CrossRef]

40. Costa, A.M.; Alfaia, R.G.D.S.M.; Campos, J.C. Landfill Leachate Treatment in Brazil—An Overview. J. Environ. Manag. 2019, 232, 110-116. [CrossRef]

41. Fernandes, A.; Pacheco, M.J.; Ciríaco, L.; Lopes, A. Review on the Electrochemical Processes for the Treatment of Sanitary Landfill Leachates: Present and Future. Appl. Catal. B Environ. 2015, 176-177, 183-200. [CrossRef]

42. Ghosh, P.; Thakur, I.S.; Kaushik, A. Bioassays for Toxicological Risk Assessment of Landfill Leachate: A Review. Ecotoxicol. Environ. Saf. 2017, 141, 259-270. [CrossRef] [PubMed] 
43. Mandal, P.; Dubey, B.K.; Gupta, A.K. Review on Landfill Leachate Treatment by Electrochemical Oxidation: Drawbacks, Challenges and Future Scope. Waste Manag. 2017, 69, 250-273. [CrossRef] [PubMed]

44. Tripathy, B.K.; Kumar, M. Suitability of Microwave and Microwave-Coupled Systems for Landfill Leachate Treatment: An Overview. J. Environ. Chem. Eng. 2017, 5, 6165-6178. [CrossRef]

45. Vodyanitskii, Y.N. Biochemical Processes in Soil and Groundwater Contaminated by Leachates from Municipal Landfills (Mini Review). Ann. Agrar. Sci. 2016, 14, 249-256. [CrossRef]

46. Peng, Y. Perspectives on Technology for Landfill Leachate Treatment. Arab. J. Chem. 2017, 10, S2567-S2574. [CrossRef]

47. Ertugay, N.; Kocakaplan, N.; Malkoç, E. Investigation of PH Effect by Fenton-like Oxidation with ZVI in Treatment of the Landfill Leachate. Int. J. Min.Reclam. Environ. 2017, 31, 404-411. [CrossRef]

48. Bogacki, J.; Marcinowski, P.; Majewski, M.; Zawadzki, J.; Sivakumar, S. Alternative Approach to Current EU BAT Recommendation for Coal-Fired Power Plant Flue Gas Desulfurization Wastewater Treatment. Processes 2018, 6, 229. [CrossRef]

49. Krzysztoszek, A.; Naumczyk, J. Landfill Leachate Treatment by Fenton, Photo-Fenton Processes and Their Modification. J. Adv. Oxid. Technol. 2012, 15, 53-63. [CrossRef]

50. Harada, T.; Yatagai, T.; Kawase, Y. Hydroxyl Radical Generation Linked with Iron Dissolution and Dissolved Oxygen Consumption in Zero-Valent Iron Wastewater Treatment Process. Chem. Eng. J. 2016, 303, 611-620. [CrossRef]

51. Dmochowski, D.; Dmochowska, A. Analiza Chromatograficzna Związków Chemicznych w Odciekach ze Składowiska Odpadów Komunalnych Poddawanych Elektroutlenianiu. Rocz. Ochr. Sr. 2015, 17, 1196-1206.

52. Dmochowska, A.; Dmochowski, D. Zawartośćsubstancjinieorganicznychorazzanieczyszczeńorganicznych w odciekach ze składowiska odpadów komunalnych w Łubnej. Pol. Przeglad Med. Psychol. Lotniczej 2011, 17, 371-380.

53. Segura, Y.; Martínez, F.; Melero, J.A.; Fierro, J.L.G. Zero Valent Iron (ZVI) Mediated Fenton Degradation of Industrial Wastewater: Treatment Performance and Characterization of Final Composites. Chem. Eng. J. 2015, 269, 298-305. [CrossRef]

54. Marcinowski, P.; Zapałowska, E.; Maksymiec, J.; Naumczyk, J.; Bogacki, J. Hydraulic Fracturing Flow-Back Fluid Treatment by ZVI/ $\mathrm{H}_{2} \mathrm{O}_{2}$ Process. Des. Water Treat. 2018, 129, 177-184. [CrossRef]

55. Bagal, M.V.; Gogate, P.R. Wastewater Treatment Using Hybrid Treatment Schemes Based on Cavitation and Fenton Chemistry: A Review. Ultrason. Sonochem. 2014, 21, 1-14. [CrossRef] [PubMed]

56. Bogacki, J.; Marcinowski, P.; Zapałowska, E.; Maksymiec, J.; Naumczyk, J. Cosmetic Wastewater Treatment by the ZVI/ $\mathrm{H}_{2} \mathrm{O}_{2}$ process. Environ. Technol. 2017, 38, 2589-2600. [CrossRef] [PubMed]

57. Du, J.; Guo, W.; Che, D.; Ren, N. Weak Magnetic Field for Enhanced Oxidation of Sulfamethoxazole by $\mathrm{Fe}^{0} / \mathrm{H}_{2} \mathrm{O}_{2}$ and $\mathrm{Fe}^{0} /$ Persulfate: Performance, Mechanisms, and Degradation Pathways. Chem. Eng. J. 2018, 351, 532-539. [CrossRef]

58. Fujioka, N.; Suzuki, M.; Kurosu, S.; Kawase, Y. Linkage of Iron Elution and Dissolved Oxygen Consumption with Removal of Organic Pollutants by Nanoscale Zero-Valent Iron: Effects of PH on Iron Dissolution and Formation of Iron Oxide/Hydroxide Layer. Chemosphere 2016, 144, 1738-1746. [CrossRef]

59. Abass, O.K.; Zhuo, M.; Zhang, K. Concomitant Degradation of Complex Organics and Metals Recovery from Fracking Wastewater: Roles of Nano Zerovalent Iron Initiated Oxidation and Adsorption. Chem. Eng. J. 2017, 328, 159-171. [CrossRef]

(C) 2019 by the authors. Licensee MDPI, Basel, Switzerland. This article is an open access article distributed under the terms and conditions of the Creative Commons Attribution (CC BY) license (http:/ / creativecommons.org/licenses/by/4.0/). 